\title{
XVI. Yüzyıl Başlarında Balkan Şehirlerinde Nüfus: Sağkol Kazaları Örneğinde Bir Tarihsel Demografi Denemesi
}

\begin{abstract}
Hanife ALACA ${ }^{1}$
Öz

Osmanlı Devleti'nde nüfus ile ilgili bilgileri içeren en kapsamlı sayımlar XVI. yüzyıl boyunca gerçekleştirilmiştir. Bu sayımlar tımar sistemiyle bağlantılı olarak devlet genelinde vergi potansiyelini belirlemek üzere yapılmış ve bunun neticesinde defterler düzenlenmiştir. Tahrir defterleri adı verilen bu defterler sayesinde bir bölgenin nüfus yapısı hakkında bilgiler elde etmek mümkün olmuştur. Çimpe Kalesi'nin alınmasından sonra Osmanlı Devleti Balkanlar'da yerleşmeye başlamıştır. Balkanlar'da devam eden fetihler sonucunda "Rumeli Eyaleti”" teșkil edilmiștir. Rumeli Eyaleti, Osmanlı’nın idari, askeri ve ekonomik yönden en önemli eyaletidir. Rumeli, idari teşkilatlanmada sağkol, solkol ve ortakol olmak üzere kazalara ayrılmışıı. Bu çalışmanın amacı, 370 Numaralı Tapu Tahrir Defteri'nden elde edilen bilgiler ışığında, Rumeli sağkol olarak adlandırılan "Edirne, Dimetoka, Ferecike, Keșan, Kız̨lağạ, Zağra-i Eskibisar, İpsala, Filibe, Tatarbaðarı, Samakov, Üskë̈b, Kalkandelen, Kirçova, Manastır, Pirlepe ve Köprülï̈” kazalarında yer alan ve şehir özelliği taşıyan yerleşmelerde Müslüman ve gayrimüslim nüfusun demografik yapılarını tespit etmektir. Böylece, Osmanlı Devleti hâkimiyetinde yer alan Balkan coğrafyasında Müslüman ve gayrimüslim mahallelerinin özellikleri ve sosyal ilişkileri ortaya konmaya çalışılacaktır. Çalışmanın özgünlüğü, XVI. yüzyıl başlarında nüfus araştırılması için dönemin ana kaynağı sayılan tahrir defterlerini analiz etmesinden kaynaklanmaktadır. Ayrıca Osmanlı idari yapısı içinde en önemli birimlerden olan Rumeli Eyaletinin nüfusu hakkında kapsayıcı başka herhangi bir çalışmanın bulunmaması da araştırmanın önemini artırmaktadır.
\end{abstract}

Anahtar Kelimeler: Balkanlar, İdari Yapı, Nüfus, Tahrir Defteri

\section{Population in Balkan Cities in The Early 16th Century: Sağkol (Right- Ramification)}

\section{District}

\section{Abstract}

In the Ottoman Empire, the most comprehensive population-based censuses were conducted in the 16th century. These censuses were conducted to determine the tax potential across the state in relation to the manorial system ("tımar" system) and, as a result, the cadastral record books were edited ("tahrir" books). Thanks to these books, called the cadastral record books, I was able to obtain information on the population structure of the region. After the acquisition of the Çimpe Castle, the Ottoman Empire began to settle in the Balkans. The "Rumeli State" was established as a result of the ongoing conquests in the Balkans. From an administrative, military and economic point of view, the Rumeli State is the most important state of the Ottoman Empire. The Rumeli Administrative Organization is divided into sağkol (rightramification), solkol (left- ramification) and ortakol (middle- ramification). The aim of this study is to determine the demographic structures of the muslim and non-Muslim population in the settlements that are involved in the districts of "Edirne, Dimetoka, Ferecik, Keşan, Kızılağaç, Zağra-i Eskihisar, İpsala, Filibe, Tatarbazarı, Samakov, Üsküb, Kalkandelen, Kırçova, Manastır, Pirlepe ve Köprülü” named as Rumeli Sağkol in the light of the data presented by the cadastral record book No. 370. In this way, the characteristics and social relations of Muslim and non-Muslim neighborhoods will be tried to be revealed in the Balkan geography under the rule of the Ottoman Empire. The originality of the work derives from the analysis of the cadastral record books, which are considered to be the main source of the period for Population Research in the early 16th century. In addition, the lack of any other inclusive population studies in the Rumeli State, which is one of the most important states of the Ottoman administrative structure, increases the importance of research.

Key Words: Balkans, Administrative Structure, Population, Tahrir Book (Cadastral Record Books)

\section{Atıf İçin / Please Cite As:}

Alaca, H. (2021). XVI. Yüzyıl Başlarında Balkan Şehirlerinde Nüfus: Sağkol Kazaları Örneğinde Bir Tarihsel Demografi Denemesi. Manas Sosyal Araștırmalar Dergisi, 10(3), 1932-1950.

Geliş Tarihi / Received Date: 05.11.2020

Kabul Tarihi / Accepted Date: 26.06.2021

\footnotetext{
${ }^{1}$ Dr. Öğretim Üyesi - Batman Üniversitesi Fen-Edebiyat Fakültesi, h.alaca67@gmail.com

iD ORCID: 0000-0002-8243-7278
} 


\section{Giriş}

Osmanlılar, Balkanlar'a Rumeli adını vermiştir. Rumeli adını Romania'dan esinlenmiş ve Bizans hâkimiyetinde olan Balkan topraklarını fethettikten sonra kullanmaya başlamıştır. Orhan Bey'in Bizans İmparatoru'nun kızı ile evlenmesi sonucunda iki devlet arasında siyasi ve askeri ittifaklar meydana gelmiş ve bu ittifaklar sonucunda ilk defa Rumeli'ye geçmişlerdir. Bizans'ta merkezi otoritenin zayıflaması ve Bizans'nn birçok devletçik ve feodal senyörlüğe bölünmüş olması Osmanlı Devleti'nin Rumeli'ye geçişini ve bu bölgede yayılmasını kolaylaştırmıştır (İnalcık, 2011, s. 1).

Orhan Bey'in oğlu Şehzade Süleyman komutasındaki ordunun Sırp-Yunan kuvvetlerini 1352 yllında yenilgiye uğratması, Osmanlıların Rumeli’ye yerleşmesini sağlayan dönüm noktası olmuştur (İnalcık, 2008, s. 232). 1354 yilında meydana gelen deprem sonucunda ise Osmanlilar savaş yapmadan Gelibolu'yu ele geçirmişlerdir. Gelibolu hem Osmanlıların Rumeli'ye yerleşmeye başlaması hem de bu bölgenin Rumeli'ye geçişte Osmanlı orduları için geçit yeri ve deniz üssü olması bakımından oldukça önemlidir (Emecen, 1996, s.1).

Osmanlıların Gelibolu'ya yerleşmesi sonucunda, Romalılar'ın yaptırdığı ve Bizanslılar'ın da kullandığı yollar boyunca fetihlere devam etmişlerdir. Bu yollarda ilerleme devam ederken Osmanlılar kendilerine uç bölgeleri belirlemişlerdir. Birinci uç; sahilden Tekfurdağı, Çorlu ve İstanbul istikameti, ikinci uç; ortadan Konru Dağ1 üzerinde, Malkara, Hayrabolu ve Vize istikametinde, üçüncü uç ise; Meriç vadisinden İpsala, Dimetoka ve Edirne istikametidir (İnalc1k, 2008, s. 233).

Zamanla solkoldaki uç; İpsala, Gümülcine, Serez, Kara Feriye ve oradan iki kola ayrillp Tırhala ve Üsküb'e, sağkoldaki uç ise Yanbolu, Karin ovas1, Pravadi'ye, oradan ikiye ayrılarak biri Tirnova ve Niğbolu'ya, diğeri Dobruca'ya kadar ulaşacaktı. Orta uç Çirmen, Zağra, Filibe’ye, oradan ikiye ayrılıp, Sofya ve Niş'e veya Köstendil ve Üsküb'e ulaşacaktır. Bu üç istikamette yapılan fetihler Rumeli'nin sağkol, solkol ve ortakol sancaklarını teşkil etmiştir (İnalcık, 2008, s. 233). Sağkol askeri anlamda solkol kadar etkili olmasa da, İstanbul'a buğday, et gibi temel besin maddelerinin sağlanması bakımından önem arz etmekteydi.

Osmanlı Devleti idari bakımdan eyalet, sancak, kaza, nahiyelere ayrılmıştır. Eyalet, Osmanlı taşra teşkilatında beylerbeyinin idaresi altında bulunan en büyük idari birimdir (İnalcık, 1995, s. 548). Sancak, Osmanlı Devleti'nde bir bölgeyi ifade etmek için ya da gelir getiren has anlamında kullanılmakta olup, XV. yüzyıldan itibaren idarî anlamda kullanıldığı ve idarî taksimatın ana birimi olarak kullanılmaya başlandığ1 görülmektedir (Şahin, 2006, s. 97-98). Sancakların oluşmasında tarihi, coğrafi, toplumsal ve iktisadi yapı göz önünde bulundurulmuştur. Ancak sancak idarî yapısını belirleyen en önemli etken askeri yapıdır. Kaza, hem kadının idari alanını belirlerken hem de belirli bir coğrafi alanı ifade etmektedir (Baykara, 2002, s. 119). Nahiye ise, bir livanın, belirli bir şehir, kasaba veya büyük yerleşim birimleri ile bunlar etrafındaki yerleşim birimlerini ifade eden ve bazen de bu yerleşim birimlerine tabi olan alanlar için kullanıldığı görülmektedir (Gökbilgin, 1964, s. 37).

Bu idari yapılanma Osmanlı Devleti'nin en büyük eyaleti olan Rumeli için de geçerliydi. Rumeli'de fetihlerin artması ile birlikte Rumeli beylerbeyliği kurulmuş ve başına da Lala Şahin Paşa getirilmiştir (Gökbilgin, 1995, s. 247). Burada fethedilen sancaklar Rumeli beylerbeyliğine bağland. Kanunî Sultan Süleyman döneminde (1526-1528) Rumeli beylerbeyliğine bağlı 27-28 sancak bulunmaktaydı (Gökbilgin, 1995, s. 250).

1530 yllında Rumeli Eyaleti Osmanlı'nın Trakya bölgesi, Bulgaristan, Moldova, Romanya ve Ukranya'nın Karadeniz sahili ile Girit dışında Yunanistan ve Adalar, Arnavutluk, Hırvatistan'ın Dalmaçya kıylları ve Sirbistan'ın büyük bir bölümünü kapsamaktaydı.

Diğer yandan Rumeli beylerbeyliği içerisinde yer alan Paşa sancağı içerisinde Sofya merkez olmak üzere kazalar, sağkol ve solkol şeklinde iki gruba ayrılmıştır. Üzerinde çalıştığımız 370 Numaralı Muhâsebe-i Vilâyet-i Rûmili Defteri'ne ${ }^{2}$ göre sağkol kazaları şu şekilde kaydedilmiştir "el-mecmu mubasebe-i kaza-i Edirne ve Dimetoka ve Ferecik. ve İpsala ve Keşan ve Zağra-i Eskihisar ve Kıə̨lağaç ve Filibe ve Tatarbazar ve

\footnotetext{
2 Bundan sonra TT.d. 370 olarak kullanılacaktır. Defterde tarih ile ilgili herhangi bir bilgi mevcut değildir. Ancak defterin Kanunî dönemine ait olduğu tahmin edilmektedir (Doğru, 2000: 19). Genel görüş defterin 1530 yilına ait olduğudur. O nedenle defter tarihi 1530 olarak kullanıldı.
} 
Üsküb ve Krrçova ve Kalkandelen ve Pirlepe ve Manastır ve Köprülï ve baær kaza-i Samakov tabi-i Liva-i Pașa" dır (T'T.d. 370, s. 186).

167 Numaralı Muhâsebe-i Vilayet-i Rumeli Defterine (TT.d. 167) göre Paşa sancağının solkol (Via Egnatia) kazalarn ise "Gümilcine, Yenice-i Karasu, Drama, Zibne, Nevrekop, Timurbisar, Siroz, Selanik, Sidrekapsi, Avtarbisar, Yenice-i V ardar, Karaverye, Serfiçe, İștin, SKestorya, Biblişste nam-ı diğer Vilkaşin, Görïceve Florine"dır.

Ortakol ise Çirmen, Zağra, Filibe ve buradan ikiye ayrılarak Sofya üzerinde Niş ve Belgrad'a ulaşırken ikinci kol da Köstendil üzerinden Üsküb'e ulaşmaktaydı (Doğru, 2000, s. 32).

\section{Balkanlar'da İskân ve Nüfus}

Osmanlı Devleti'nin iskân politikası, temel olarak devlet otoritesini tesis etmek ve Türk-İslam geleneği doğrultusunda cihanşümul bir devlet kurmak amacı taşımaktadır. Bu amaçla devlet, hâkimiyeti altında bulunan reayayı gerek teşvik ederek gerekse mecburi olarak belirli koşullarda uygun bulduğu mekânlara yerleştirmeye çalışmıştır (Çalık, 2005, s. 70). Balkanlar'da iskân süreci de bu çerçevede gerçekleşmiştir ${ }^{3}$. Gelibolu'nun fethedilmesiyle birlikte Osmanlı Devleti Anadolu'dan nüfus getirerek bu bölgeye yerleştirmiştir. Ayrıca, Anadolu'dan sürülen göçebeler ve Tatar aşiretleri de Balkanların iskânı için bu bölgeye sevk edilmiştir.

Balkanlarda uygulanan bir diğer iskân siyaseti vakıflar yoluyla uygulanmışıtı́ . Padişah ve devletin ileri gelenleri başta olmak üzere birçok yönetici ve ilmiye sınıfı mensupları ve varlıklı insanlar fethedilen bölgelerde vakıflar kurmuşlardır. Kurulan bu vakıflar sayesinde yeni iskân mahalleri kurulmuş ve böylece fazla nüfus buralara yerleştirilmiştir. Osmanlı Devleti'nin Balkanlar'da uyguladığı iskân siyaseti esas itibarryla gönüllü olarak Anadolu'dan gelen büyük nüfus kitlelerini bu bölgeye yerleştirmek olmuştur (Aktepe, 1951-53, s. 304).

Nüfus, bir ülkede, bir bölgede yerleşim birimlerinde yaşayan insan sayısını ifade eder. Osmanlı Devleti'nde XV. ve XVI. yüzylllarda nüfus ile ilgili bilgiler Tapu-Tahrîr Defterlerinden elde edilmektedir. Bu defterler, iskân alanlarının adlarını, sınırlarını ve bir yerin idarî hususiyetini ortaya koyacak mahiyettedir. Keza bu iskân alanlarında yaşayan nüfusun sayısını, yapısını ve zaman içerisinde meydana gelen değişimleri ve bu değişimlerin sebeplerini ortaya çıkaracak istatistikî verileri ihtiva etmektedir.

Osmanlı Devleti hâkimiyeti altında bulunan Müslüman ve gayrimüslim olarak kategorize etmiştir. Kişileri ve grupları birbirinden ayıran temel unsur din olarak görülmektedir. Gayrimüslim, Müslümanlar dışındaki tüm gruplar için kullanılırdı. Üzerinde çalıştı̆̆ımız tahrir defterine göre XVI. yüzyılın ikinci yarısında gayrimüslim reaya defterlere "gebran" 5 ve "zımmi"6 olarak kaydedilmiştir. Baz1 defterlere bazen farklı grupları ifade etmek için ise "Yahudiyan" ve "Rumiyan" ifadeleri kullanılmıştır.

\section{Nüfusun Kazalara Göre Dağılımı}

Yetişkin erkek nüfus tahrir defterlerine kaydedilirken hane ${ }^{7}$, mücerred ${ }^{8}$ gibi ifadeler kullanılmıştır. Tahrir defterlerindeki bu kayıtlar bize bir bölgedeki kesin nüfusu vermemektedir. Tahrir defterleri bilindiği üzere devletin bütün gelir kaynaklarını ve vergi mükelleflerini tespit etmek amacıyla tutulmuştur. Ancak bu defterlerin tutulma amacı her ne kadar bir bölgenin toplam nüfusunu ele almak olmasa da, XV. ve XVI. yüzyıl nüfus ile ilgili bilgiler Tahrir Defterlerinde elde edilmektedir. Bu defterler iskân alanlarının adlarını, sınırlarını ve bir yerin idarî özelliklerini ortaya koyacak mahiyettedir. Keza, bu iskân alanlarında yaşayan

\footnotetext{
3 Balkanlar'da İskân ile ilgili yayınlanmış eserler için bkz. Ömer Lütfi Barkan, "Osmanlı İmparatorluğunda Bir iskân ve Kolanizasyon Metodu Olarak Vakıf ve Temlikler I, İstila Devirlerinin Türk Dervişleri ve Zâviyeler”, VD, II, (1942), s.279-386; Ömer Lütfi Barkan, Barkan, "Osmanlı İmparatorluğunda Bir İskân ve Kolanizasyon Metodu Olarak Sürgünler”, İÜ IFM, XI (1949-50), s.524-569; Münir Aktepe, "XIV-XV. Asırlarda Rumeli’nin Türkler Tarafından İskânına Dair”, Türkiyat Mecmuası, X (1951-53). S.299-312; Cengiz Orhonlu, Osmanl Imparatorluğunda Aşiretleri İskân Tessebbüsü (1691-1696), İstanbul Üniversitesi Edebiyat Fakültesi Yay., İstanbul 1963; Hasan Kaleshi, “Türkler'in Balkanlar’a Girişi ve İslâmlaştırılma” İstanbul Üniversitesi Edebiyat Fakültesi Tarih Enstitüsü Dergisi, Say1 10-11, 1970-80, İstanbul 1981, s.177-194; S1ddık Çalık, Çirmen Sancăğ Örneğinde Balkanlar'da Osmanl Düzeni (15.-16. Yüzynllar), Bosna-Hersek Dostları Vakfi Yayınları, Ankara 2005.

${ }^{4}$ Ayrıntılı bilgi için bkz. Ömer Lütfi Barkan (1942). “Osmanlı İmparatorluğunda Bir iskân ve Kolanizasyon Metodu Olarak Vakıf ve Temlikler I, İstila Devirlerinin Türk Dervişleri ve Zâviyeler. VD, II, s.279-386.

${ }^{5}$ Gebran, ataeşperest, mecusi, zerdüşt anlamina gelmektedir (Sami, 2001, s. 1142).

${ }^{6}$ Zımmi, Osmanlı Devleti'ne himayesinde olan gayrimüslim reaya için kullanılan bir terimdir (Sami, 2001, s.649)

${ }^{7}$ Hane, Osmanlı Devleti’nde nüfus ve vergi birimi olup, aileyi ifade etmek için kullanılmıştır. Bkz. (Göyünç, 1997, s. 552).

${ }^{8}$ Mücerred, buluğ çağına gelmiş, bekâr erkekler için kullanılan bir terimdir. Bkz. (İnalcık, 1987, s.XXX)
} 
nüfusun yapısını, sayısını ve zaman içerisinde meydana gelen değişimleri ve değişimlerin sebeplerini ortaya ç1karacak pek çok istatistiki veriyi içermektedir.

Bu çalısmada Rumeli sağkol kazalarında nefs olarak adlandırılan şehirlerin nüfusu değerlendirilmiştir. Genel olarak tahrir defterlerinde bulunan "nefs" kelimesi şehir olarak tanımlanmaktadır. Yalnız, nefs kelimesi de şehir kavramını tam olarak ifade etmemektedir. Faroqhı, Anadolu şehirlerini tanımlarken XVI. yüzyll üzerine yapılan çalışmalarda orta ölçekli bir şehrin 1000 ila 3000 vergi mükellefi bulunduğunu, 4001000 nefer nüfusu barındıran yerleşim birimlerinin ise küçük şehir sayıldığını ifade etmiştir (Faroqhı, 1984, s. 9). Yine de bu çalışmada, nüfus sayısına bakılmaksızın sağkol kazalarının nefs olarak ifade edilen yer, şehir olarak adlandırılmıştır. Şehirlerin temel yapı birimi ise mahallelerdir. Osmanlı şehrinde mahalle, insanların birbirini tanıdığı ve soyla dayanışma içerisinde olan kişilerden meydana gelen topluluktur (Ergenç, 1984, s. 690).

Rumeli Eyaleti sağkol kazalarında Müslüman nüfus hane, mücerred olarak kaydedilmiştir. Müslüman nüfus bu kazalardan en fazla Edirne'de toplanmıştır. Edirne şehrinde 144 mahallede toplam 2880 Müslüman hane ve 387 mücerred kaydedilmiştir (TT.d. 370, s. 1-4). Ayrıca bu Müslüman mahallelerde yaşayan 47 hanede gayrimüslim nüfus bulunmaktadır. Bu da Müslüman ve gayrimüslim unsurların birlikte yaşama kültürünün var olduğunun bir göstergesidir. Bununla birlikte, Edirne şehri gerek mahalle sayıs1 gerekse nüfus bakımından sağkol kazaları içerisinde ilk sırada yer almaktadır.

Edirne, İstanbul'un fethine kadar Osmanll’ya başkentlik yapmış bir şehirdir. Osmanlı’nın başkenti yapılmasından dolayı sarayın burada inşa edilmesi ve hem yöneticilerin hem de askerlerin buraya taşınmasını zorunlu kılacaktır. Bu da doğal olarak şehrin nüfusunun artmasına neden olacaktır. Bulunduğu coğrafi konum itibarryla ticari yollar üzerinde bulunması Edirne şehrinin nüfusunun gelişme göstermesinin önemli bir nedenidir. Edirne şehrinin fetihten itibaren nüfusunun arttığını, üzerinde çalıştı̆ıııı 1530 yılına ait defterde de Edirne nüfusunun sağkol kazaları içerisinde ilk sırada yer aldığ1 görülmektedir.

Tablo 1. Edirne Şebrinde Nüfusun Maballelere Göre Dağglımı

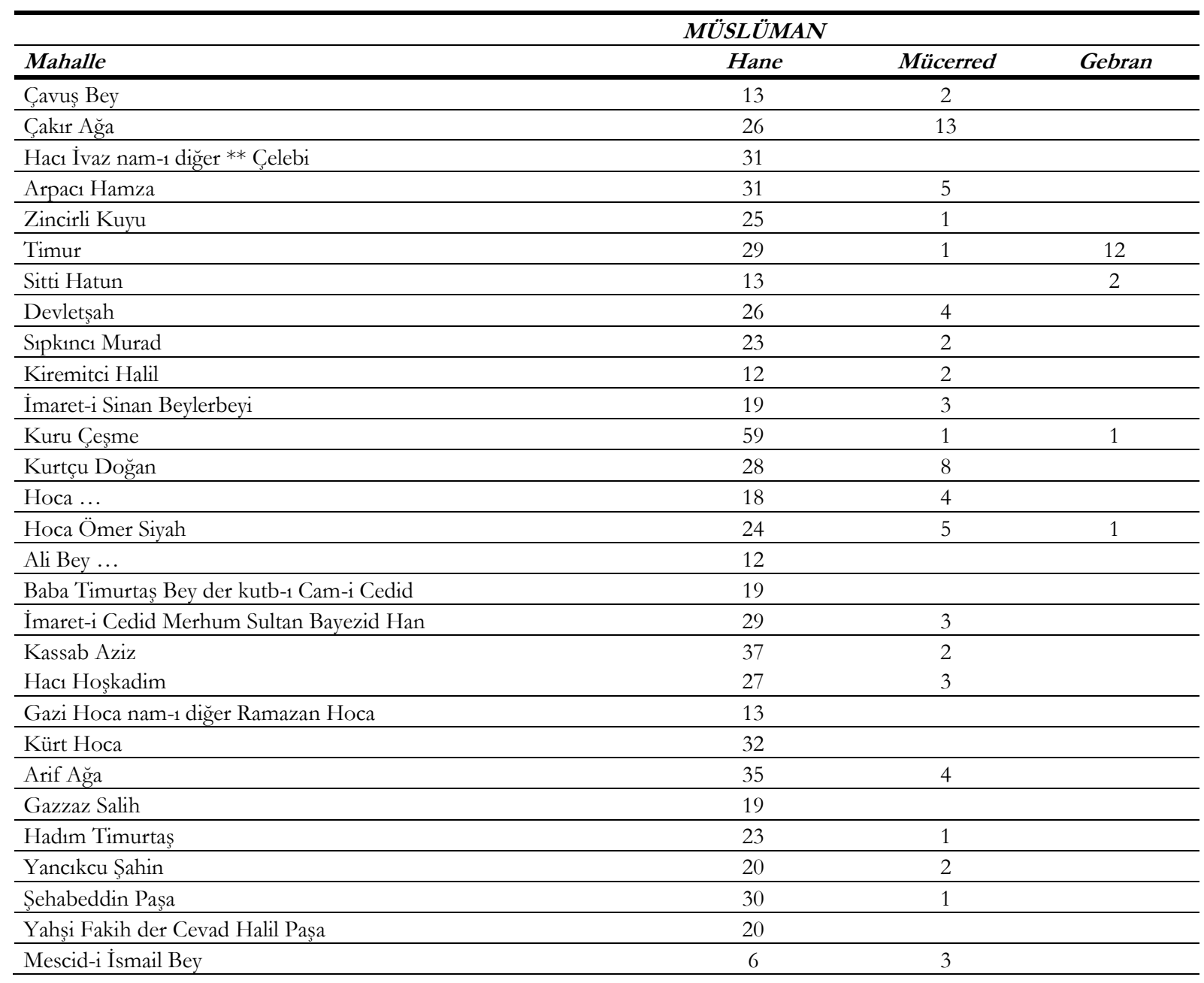


ALACA

XVI. Yüzyıl Başlarında Balkan Şehirlerinde Nüfus: Sağkol Kazaları Örneğinde Bir Tarihsel Demografi Denemesi

\begin{tabular}{|c|c|c|}
\hline Kebe Yayıc1 & 14 & 2 \\
\hline Fedlulllah Paşa & 17 & 6 \\
\hline Cami-i Sefer Şah & 5 & 2 \\
\hline Beyazid-i Sufi & 13 & \\
\hline Mezid Bey & 15 & 2 \\
\hline Hacı Doğan & 29 & 2 \\
\hline Maruf Hoca & 33 & 5 \\
\hline Mihail Koçi? & 8 & 2 \\
\hline Cami-i Atik & 17 & 16 \\
\hline İmaret-i Muradiye & 45 & 14 \\
\hline Doğan & 18 & 8 \\
\hline Kapucu nam-1 diğer Karaca Bey & 20 & \\
\hline Hadım Balaban & 12 & 4 \\
\hline ** Balaban & 14 & 3 \\
\hline Hacı Osman nam-1 diğer Fındık Osman & 12 & \\
\hline Ayşe Hatun nam-1 diğer Kapucu Sinan Bey & 28 & \\
\hline Gülbahar Hatun & 11 & \\
\hline Mevlana Veliyüddin & 25 & 2 \\
\hline Zaviye-i Rüstem Çelebi & 5 & 2 \\
\hline Mescid-i Bazirgan & 36 & 1 \\
\hline \multicolumn{3}{|l|}{ Bazirgan Bali nam-1 diğer Hoca Bali } \\
\hline Cami-i Cedid nam-1 diğer Altunc1 & 6 & \\
\hline Finduk Dede & 67 & 6 \\
\hline Selçuk Hatun & 26 & \\
\hline Veliyüddinzade & 7 & 1 \\
\hline Mevlana Fahreddin Acemi & 15 & 1 \\
\hline Şehabeddin Paşa & 25 & 9 \\
\hline Veled-i Kuhteci & 11 & 1 \\
\hline Hamam Kasım Paşa & 20 & \\
\hline Derviş Ab1 & 11 & 2 \\
\hline Mescid-i Veli Çelebi & 17 & 1 \\
\hline \multicolumn{3}{|l|}{ Zemin-i Vak-1 İbrahim Ağa } \\
\hline Hazinedarbaşı Sinan Bey & 23 & 2 \\
\hline Karabulud & 18 & 1 \\
\hline \multicolumn{3}{|l|}{ Der Odaha-yı Mübarek Ağa } \\
\hline Bekce & 17 & 4 \\
\hline Sevindik Fakih & 26 & 4 \\
\hline Köhne Kadı & 5 & 1 \\
\hline Hatun-1 Saruca Paşa & 4 & \\
\hline Der Odaha-yı Abdullah & 3 & \\
\hline Darbhane & 6 & \\
\hline Noktacizade & 14 & \\
\hline Baba Timurtaş & 47 & 2 \\
\hline Rakkas Ali Bey & 21 & 4 \\
\hline İbrahim Paşa & 35 & 3 \\
\hline Eskicü Hacı Hamza & 15 & 1 \\
\hline Firuz A ğa & 32 & \\
\hline Hadım Firuz & 20 & 6 \\
\hline Hac1 Safa & 20 & 1 \\
\hline Katib-i Cev & 15 & \\
\hline Arpac1 Ahmed & 14 & 2 \\
\hline İmaret-i Mezid Bey & 26 & 1 \\
\hline Mehmed Ağa & 28 & 1 \\
\hline Alemderan & 18 & \\
\hline Hoca Siyah nam-1 diğer Mescid-i Sinan & 7 & 1 \\
\hline Zevce-i Saruca Paşa & 21 & 2 \\
\hline Hac1 İslam & 5 & 1 \\
\hline Hac1 Mercimek & 24 & 1 \\
\hline Takyeci Balı & 7 & \\
\hline
\end{tabular}




\begin{tabular}{|c|c|c|c|}
\hline Kara Yakub & 10 & 1 & \\
\hline Veled-i Arab & 30 & 8 & \\
\hline Hamid Bey & 3 & & \\
\hline Karac Hacı nam-1 diğer Kazgancı & 23 & 1 & \\
\hline Daye Hatun & 16 & 1 & \\
\hline Mescid-i Balaban Ağa & 14 & & \\
\hline Dukalci? & 32 & & \\
\hline Berkuk Ağa & 23 & 4 & \\
\hline Hamam Bahşi Fakih & 12 & & \\
\hline Kinc1 Firuz & 33 & 1 & \\
\hline Cillah Hac1 & 27 & & \\
\hline Umur Bey & 17 & & \\
\hline Cami-i Kasım Paşa & 25 & 5 & 4 \\
\hline Medrese-i Ali Bey & 32 & & \\
\hline Tahtü'l-Kıla & 14 & 2 & \\
\hline Şehabeddin & 21 & & \\
\hline Medrese-i Şah Melek & 42 & 4 & \\
\hline Medrese-i Kad1 & 16 & & \\
\hline Çırağc1 & 20 & 4 & \\
\hline İmaret-i Mihal Bey & 47 & 10 & \\
\hline Sarraf Hact Ahmed & 32 & 1 & \\
\hline Hacı Kulagöz & 22 & 2 & \\
\hline Hac1 Halil Attar & 17 & 3 & 6 \\
\hline Odaha-yı Süleyman Paşa & 8 & & \\
\hline Saruca Paşa & 20 & & \\
\hline Mescid-i Veled Takurlu & 20 & & \\
\hline Zaviye-i Şeyh Şuca & 16 & & \\
\hline İmaret-i Yıldırım Han & 25 & 3 & \\
\hline Mümin Hoca & 21 & 3 & \\
\hline Hac1 Bedreddin & 18 & 1 & \\
\hline Cami-i Noktacızade & 8 & & \\
\hline Mescid-i Hacı Alaaddin & 14 & & 15 \\
\hline Daru's-sade & 29 & & \\
\hline Ahi Hasan & 18 & 2 & \\
\hline Zevce-i Firuz A ğa & 45 & 2 & \\
\hline Veled-i Sabuni nam-1 diğer ibn-i Çelebi & 9 & 2 & \\
\hline Gendim Gün? & 9 & 2 & \\
\hline ** Cami & 23 & & \\
\hline Hac1 Halil & 49 & & \\
\hline Hacı Bayezid-i mezkûr & 1 & & \\
\hline Mescid-i Mahmud Ağa & 23 & & \\
\hline Hasan Paşa & 35 & & \\
\hline Hac1 İslam & 22 & & \\
\hline Sinan Bey ve Tabib Cafer & 9 & 1 & \\
\hline Sabunhane nam-1 diğer Sabuncuyan & 23 & 1 & \\
\hline Zağanos Subaş1 & 41 & 4 & \\
\hline Üsküfcü Hızır & 28 & & 1 \\
\hline Hac1 Murad & 6 & & \\
\hline Mirahor Ayas Bey & 11 & 3 & \\
\hline Hizır Ağa & 24 & 2 & 4 \\
\hline Mescid-i ... Ağa & 10 & & \\
\hline Balaban Paşa & 35 & & \\
\hline Der odaha-y1 vakf-1 mezbur & & 7 & \\
\hline Der odaha-y1 mezbur & & 3 & \\
\hline Dekakin-i mezbur der Enderun Muytaban & & 5 & \\
\hline TOPLAM & 2880 & 287 & 47 \\
\hline
\end{tabular}

Ayrıca, Edirne şehrinde “Cemaat-i Yahudiyan” başlı̆̆1 altında sekiz Yahudi cemaati mevcuttur. Bu cemaatlerde toplam 204 hane ve 6 mücerred kayıtlıdır (TT.d. 370, s. 4). Yahudi cemaatlerin Tablo-2'de 
ALACA

XVI. Yüzyıl Başlarında Balkan Şehirlerinde Nüfus: Sağkol Kazaları Örneğinde Bir Tarihsel Demografi Denemesi

görüldüğü üzere geldikleri bölgelerin isimlerine göre kaydedildiği anlaşılmaktadır. Burada yaşayan Yahudilerin XV. yüzyılda Avrupa'nın birçok bölgesinden zorunlu göçe tabi tutulan Yahudiler olması muhtemeldir. Yahudilerin bir bölümünün II. Bayezid tarafindan gönderilen gemilerle Osmanlı topraklarına getirildiği bilinmektedir (Turan, 1992, s. 236). Üzerinde çalıstığımız defterin 1530 yllına ait olması bu varsayımı güçlendiren önemli bir etkendir.

Tablo 2. Edirne Şebrinde Yabudi Cemaati ve Nüfusu

\begin{tabular}{lcc}
\hline Cemaat $\boldsymbol{A d \boldsymbol { }} \boldsymbol{}$ & Hane & Mücerred \\
\hline Katalan & 32 & 2 \\
\hline Portugal & 36 & 2 \\
Alaman & 7 & 2 \\
\hline İspanya & 34 & \\
\hline Poliyye & 25 & \\
\hline Geroz & 27 & \\
\hline Toledo & 13 & 6 \\
\hline Aragon & 27 & \\
\hline TOPLAM & 204 & \\
\hline
\end{tabular}

Edirne şehrinde "Cemeati-i Zimmiyan" başlı̆̆ın altında gayrimüslimlerin yaşadığı 19 mahalle bulunmaktadır. Bu mahallelerde 472 hane ve 7 mücerred mevcuttur (TT.d. 370, s. 5). Bu Hristiyan grupların yanında ayrıca Müslüman mahallelerde (Timur 12, Sitti Hatun 2, Cami-i Kasım Paşa 4, Hacı Halil Attar 6, Mescid-i Hacı Alaaddin 15, Hızır Ağa 4, Kuru Çeşme, Hoca Ömer Siyah, Hacı Safa, Üsküfcü Hızır'da 1'er tane) yaşayan toplam 47 hane Hristiyan mevcuttur (TT.d. 370, s. 1-4).

Tablo 1 ve Tablo 3’te görüldüğü üzere Edirne şehrinde mahalle isimleri genel olarak kişi adlarından oluşmaktadır.

Tablo 3. Edime Şebrinde Gayrimüslimlerin Mahallelere Göre Dağgllmı

\begin{tabular}{lcc}
\hline Mahalle Ad & Hane & Mücerred \\
\hline Ayo Dimitre & 65 & 2 \\
\hline Papa Yalori & 15 & 2 \\
\hline Hristos & 41 & \\
\hline İstiranikos & 15 & \\
\hline Ayo Duhtini & 51 & \\
\hline Ayo Apostol & 21 & 1 \\
\hline Ayo Yani Bimankos & 22 & \\
\hline Medropolid & 18 & \\
\hline Kurtcu Dogan & 4 & 1 \\
\hline Kalomolari & 20 & \\
\hline İrhi İstiranikos & 20 & \\
\hline Papa Vetac & 8 & \\
\hline Aya Yorgi & 11 & 1 \\
\hline Papa Kayanos & 33 & 7 \\
\hline Ayo Atanas & 24 & \\
\hline Hamam-1 Abdullah Bey & 50 & \\
\hline Prodornos & 37 & \\
\hline Ayo Stefano & 7 & \\
\hline Aya Nikola & 10 & \\
\hline TOPLAM & 472 & \\
\hline
\end{tabular}

Rumeli'de sağkol kazalarından biri olan Dimetoka, Osmanlı döneminde bir ilim merkezidir. Edirne'nin fethedilmesine kadar I. Murad, Şehzade Musa Çelebi ve II. Mehmed burada ikamet etmiștir (Kıel, 1994, s.305). Yıldırım Bayezid'in inşasına başladığı ve oğlu I. Mehmed'in 1421'de tamamladığ1 Balkanlar'ın en büyük camisi Dimetoka'nın burada olması Dimetoka'nın fethinden itibaren önemli bir yer olduğunu ortaya koymaktadır (Kıel, 1994, s.305). Bu yerleşim yerinde Osmanlıların uyguladığ1 iskân politikası ise bu bölgeye dışarıdan getirilen Türk ailelerini yerleştirmek şeklinde olmuştur (Kıel, 1994, s.306).

Dimetoka şehrinde 15 Müslüman mahallesinde 166 Müslüman hane ve 44 nefer mücerred kayıtlıdır (T'T.d. 370, s. 19). Buna karşıllk 4 gayrimüslim mahallede 145 hane ve 3 nefer mücerred yaşamaktadır 
(TT.d. 370, s. 19). "Dimitri nam-1 diğer Yahudiyan" mahallesi adından da anlaşıldığı üzere bir Yahudi mahallesidir (TT.d. 370, s. 19).

Tablo 4. Dimetoka Şehrinde Nüfusun Maballelere Göre Dağzlımı

\begin{tabular}{|c|c|c|c|c|c|}
\hline \multicolumn{3}{|c|}{ MÜSLÜMAN } & \multicolumn{3}{|c|}{ GAYRIMÜSLIMM } \\
\hline Mahalle & Hane & Mücerred & Mahalle & Hane & Mücerred \\
\hline Oruç Bey & 5 & & Köse Papas & 45 & 1 \\
\hline Medrese & 6 & 3 & Dimitri nam-i diğer Yahudiyan & 15 & \\
\hline Circir & 10 & 3 & Ayo Todor & 37 & 2 \\
\hline Kuyumcu & 18 & 2 & Manastır & 48 & \\
\hline$\ldots$ & 10 & 3 & & & \\
\hline Cami & 4 & 1 & & & \\
\hline Tatarlu & 12 & 4 & & & \\
\hline Kulak & 4 & 1 & & & \\
\hline Köprübaşı & 17 & 4 & & & \\
\hline Doğan Bey & 1 & & & & \\
\hline Hamza Kurd Bey & 12 & 5 & & & \\
\hline Bazarlu? Bey & 15 & 7 & & & \\
\hline Debbağ nam-1 diğer Abdal & 19 & 4 & & & \\
\hline$\ldots$ & 8 & 3 & & & \\
\hline Hoca nam-1 diğer & 24 & 4 & & & \\
\hline Dimetoka & 1 & & & & \\
\hline TOPLAM & 166 & 44 & TOPLAM & 145 & 3 \\
\hline
\end{tabular}

Tablo 4'de adı geçen "Debbağ nam-1 diğer Abdal" mahallesinin Dimetoka'da kurulmuş en eski zaviye olan Abdal Cüneyd Zaviyesi etrafinda bulunun debbağlardan adını aldığı anlaşılmaktadır. Bölgenin ilk tahrir defterlerinden 1485 yllına ait Tahrir Defterleri'nde "Mahalle-i Debbağlar ki Abdal Cüneyd mahallesi dahi dirler" şeklinde mahallenin adının yer alması ilk dönemlerden itibaren bu mahallenin var olduğunu göstermektedir (TT.d, 20, s. 141).

Ferecik, Rumeli sağkol kazalarından Akdeniz’e kıyısı olan en güneydeki yerleşim birimidir. 1530 yllında Ferecik şehrinde 7 mahallede 133 hane ve 61 mücerred Müslüman yaşamaktadır (TT.d, 370, s. 43). Gayrimüslimler ise "mahalle-i gebran" başlı̆̆1 altında toplam olarak verilmiştir. Buna göre Ferecik şehrinde 37 gayrimüslim nüfus tespit edilmiştir (TT.d, 370, s. 43). Görüldüğü üzere Müslüman ve gayrimüslimler ayrı mahallelerde yaşamaktadırlar. Müslüman nüfusun en kalabalık olduğu mahalle Cami Mahallesidir. Tablo-5'de görüldüğü üzere mahalle isimlerinin genel olarak önemli kişilerin adlarından ve dini yapılardan aldığı görülmektedir.

Tablo 5. Ferecik Șebrinde Nüfusun Mahallelere Göre Dă̆glımı

\begin{tabular}{lcc}
\hline Mahalle & Hane & Mücerted \\
\hline Şeyh Mescidi nam-1 diğer Subaş1 & 26 & 17 \\
\hline Hac1 Yusuf & 7 & 1 \\
\hline Hayreddin & 29 & 10 \\
\hline Şeyh nam-1 diğer Hacı Fakih & 24 & 5 \\
\hline Timurhan & 12 & 4 \\
\hline Cami & 34 & 24 \\
\hline Hacı Durmuş & 1 & $\mathbf{6 1}$ \\
\hline TOPLAM & $\mathbf{1 3 3}$ & \\
\hline Mahalle-i Gebran & 37 & \\
\hline
\end{tabular}

Keşan, Rumeli sağkol kazalarından az sayıda nüfusu barındıran şehirler arasında Köprülü şehrinden sonra ikinci sırada yer almaktadır. Keşan şehrinde Müslüman nüfus mevcut iken, gayrimüslim nüfusa rastlanmamıştır. Sadece Mercan Mahallesi bulunan Keşan'da bu mahallede 37 hane ve 7 mücerred Müslüman nüfus tespit edilmiştir (TTT.d, 370, s. 51).

1530 yılında Kızılağaç şehri de az sayıda nüfus barındıran şehirler arasında yer almaktadır. 4 Müslüman mahallede 47 hane ve 18 mücerred barınmaktadır (TT.d, 370, s. 57). Yine Keşan şehrinde olduğu gibi Kızılağaç şehrinde de sadece Müslüman nüfusun yaşadığı tespit edilmiştir. 
ALACA

XVI. Yüzyıl Başlarında Balkan Şehirlerinde Nüfus: Sağkol Kazaları Örneğinde Bir Tarihsel Demografi Denemesi

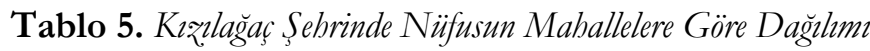

\begin{tabular}{lcc}
\hline Mahalle & Hane & Mücerred \\
\hline Yakub-1 Kassab nam-1 diğer Reis oğlu & 7 & 3 \\
\hline İsa Fakih & 7 & 1 \\
\hline Şaban Fakih & 20 & 13 \\
\hline Hatib & 13 & 1 \\
\hline TOPLAM & $\mathbf{4 7}$ & $\mathbf{1 8}$ \\
\hline
\end{tabular}

Sadece Müslüman nüfusa sahip Rumeli sağkol kazalarından bir diğeri de Zağra-i Eskihisar'dır. 1530'da Zağra-i Eskihisar şehrinde 18 mahalle bulunmaktadır. Bu mahallelerde 513 hane ve 203 mücerred barınmaktadir (TT.d, 370, s.67).

Tablo 6. Zăgra-i Eskihisar Şehrinde Nüfusun Mahallelere Göre Dă̆ılımı

\begin{tabular}{lcc}
\hline Mahalle & Hane & Mücerred \\
\hline İmaret & 28 & 22 \\
\hline İbrahim Subaşı nam-1 diğer Kaya & 27 & 4 \\
\hline Veled-i İvaz & 41 & 5 \\
\hline Cami & 41 & 20 \\
\hline Çerçi Murad & 37 & 15 \\
\hline Hacı Hasan nam-1 diğer Derzi Yusuf & 24 & 6 \\
\hline Hacı Malkoç & 16 & 6 \\
\hline Cüneyd & 19 & 12 \\
\hline Mihaliçlü & 29 & 11 \\
\hline$\ldots$ & 28 & 16 \\
\hline Kalburcu & 19 & 5 \\
\hline Hacı Temürhan nam-1 diğer Cüllahan & 20 & 12 \\
\hline Hacı Mahmud & 39 & 11 \\
\hline Hamid Fakih & 31 & 22 \\
\hline Debbağan & 49 & 5 \\
\hline Havuccılar & 3 & 15 \\
\hline Hasan Fakih.. & 19 & 203 \\
\hline TOPLAM & 43 & 513 \\
\hline
\end{tabular}

İpsala şsehrinde 14 Müslüman mahalle ve bu mahallelerde yaşayan 403 hane ve 142 mücerred bulunmaktadır (TT.d, 370, s. 78). Ayrıca, gayrimüslim mahalleleri bulunmayan şehirde Köprü Mahallesinde yaşayan 1 hane gayrimüslim nüfus mevcuttur.

Tablo 7. İsala Şebrinde Nüfusun Maballelere Göre Dă̆ılımı

\begin{tabular}{|c|c|c|c|}
\hline Mahalle & Hane-i Müslim & Mücerred & Hane-i Gebr \\
\hline Hoca Hamza nam-1 diğer Camilü & 29 & 1 & \\
\hline Serrac İlyas & 53 & 6 & \\
\hline Cami-i Köhne & 20 & 3 & \\
\hline Debbağan & 24 & 4 & \\
\hline Bayram Bey & 27 & 10 & \\
\hline Köprü & 41 & 1 & 1 \\
\hline Müderris nam-1 diğer İdris & 21 & 60 & \\
\hline Hac1 Giran & 26 & 13 & \\
\hline Hasan Halife & 6 & 1 & \\
\hline Kazanc1 & 21 & 6 & \\
\hline Mübarekşah & 35 & 13 & \\
\hline Akarca nam-1 diğer Kurşunlar & 29 & 9 & \\
\hline Kapucu & 68 & 15 & \\
\hline Kolak Ali & 3 & & \\
\hline TOPLAM & 403 & 142 & $\overline{1}$ \\
\hline
\end{tabular}


1530 yılında sağkol kazalarında Edirne şehrinden sonra en fazla nüfusu barındıran şehir Filibe'dir. 29 mahallede toplam 609 hane ve 127 mücerred Müslüman bulunmaktadır (TT.d, 370, s.85). Ayrıca 4 gayrimüslim mahalle ve 2 cemaat bulunan Filipe şehrinde 147 hane ve 16 mücerred gayrimüslim nüfus tespit edilmiştir (TT.d, 370, s. 86).

Filibe'nin kesin fethinden sonra Osmanlı'nın burada yoğun bir şekilde iskân politikası uyguladığı bilinmektedir. Devletin, Anadolu'dan getirdiği aşiretleri bu bölgeye yerleştirmesi Filibe'nin geniş ölçüde şenlenmesine neden olmuştur (K1el, 1996, s. 80). XVI. yüzyllara gelindiğinde de Filibe'nin nüfusunun diğer Rumeli sağkol kazalarına göre ilk sıralarda yer alması bu iskân politikasının bir sonucu olmalıdır. 1530 yılına gelindiğinde 513 Müslüman hane ve 203 gayrimüslim hane barındırıyor olması bunun bir göstergesidir. Ayrıca gayrimüslim mahalleler içerisinde bir Yahudi ve bir çingene mahallesi bulunmaktadır. Bu mahallelerde 66 hane nüfus mevcuttur (TT.d, 370, s. 86).

Tablo 8. Filibe Şehrinde Nüfusun Mahallelere Göre Dağglımı

\begin{tabular}{|c|c|c|c|c|c|}
\hline \multicolumn{3}{|c|}{ MÜSLÜMAN } & \multicolumn{3}{|c|}{ GAYRIMÜSLİM } \\
\hline Mahalle & Hane & Mücerred & Mahalle & Hane & Mücerred \\
\hline Haracc1 Hamza Bali & 41 & 5 & Hisar İçi & 26 & 5 \\
\hline İdris Hoca & 17 & 4 & Bazar İçi & 14 & 2 \\
\hline Cam-i Kebir & 36 & 7 & $\ldots$ & 17 & 3 \\
\hline Hacı Ahmed & 23 & 4 & $\ldots$ & 24 & 3 \\
\hline Musalla & 25 & 5 & TOPLAM & 81 & 13 \\
\hline Tabbağ Hisar1 & 18 & 2 & Cemaat-i Yahudiyan & 33 & 1 \\
\hline Islahan Bey & 15 & 4 & Cemaat-i Kibtiyan & 33 & 2 \\
\hline Hac1 Ömer & 22 & 5 & & & \\
\hline ... Hac1 & 7 & 10 & & & \\
\hline Hacı Böneri & 12 & 1 & & & \\
\hline Yakub Fakih & 17 & 2 & & & \\
\hline Hacı Hamid & 15 & & & & \\
\hline ... Hoca nam-1 diğer ..oğlu & 18 & & & & \\
\hline Çukacı Sinan & 21 & 1 & & & \\
\hline Hacı Mesud & 9 & 1 & & & \\
\hline Veled-i Kasım & 27 & 6 & & & \\
\hline Koca Hüseyin & 19 & 10 & & & \\
\hline$\ldots$ & 7 & 2 & & & \\
\hline Cüneyd & 7 & 8 & & & \\
\hline Tur-beyi Hoca & 20 & 9 & & & \\
\hline Veled-i Rüstem & 14 & 11 & & & \\
\hline Hoca Bey & 17 & 6 & & & \\
\hline Hacı Sinan nam-1 diğer Kaya Mescidi & 22 & 3 & & & \\
\hline Bahşayiş Ağa & 42 & 8 & & & \\
\hline Tatarlar & 47 & 4 & & & \\
\hline Korucu & 27 & & & & \\
\hline$\ldots$ & 26 & 3 & & & \\
\hline Keçeci İne Beyi & 22 & 2 & & & \\
\hline Veled-i Şükran & 16 & 4 & & & \\
\hline TOPLAM & 609 & 127 & & & \\
\hline
\end{tabular}

Osmanlı Devleti'nin Balkanlar'da belirli bir iskân politikası uyguladığı bilinmektedir. Bu iskân politikalarından biri de 1418 Tatar topluluğunun Balkanlar'da Filibe yakınlarına yerleştirilmesidir (Kıel, 1996, s. 80). Bu topluluğun daha sonra Tatarpazarı'nın kurulmasına neden olduğu bilinmektedir (Acehan, 2008, s. 18). Tatarpazarı, Balkanlar sağkol kazalarından sadece Müslüman nüfusu barındıran şehirlerden biridir. 7 mahallesi bulunan Tatarpazarr'nda toplam 126 hane ve 16 mücerred bulunmaktadır (T'T.d, 370, s. 109). 
Tablo 8. Tatarpazar Şehrinde Nüfusun Mahallelere Göre Dağılımı

\begin{tabular}{lcc}
\hline Mahalle & Hane & Mücerred \\
\hline$\ldots$ & 19 & 3 \\
\hline$\ldots$ Mustafa & 28 & 3 \\
\hline İmaret-i Ahmed Bey bin Evranos Bey & 8 & \\
\hline Cami & 29 & 2 \\
\hline Mustafa Karaman nam-1 diğer Çarşu Mahallesi & 23 & 3 \\
\hline Nayib Hamza & 16 & 2 \\
\hline Cami-i İshak Çelebi & 3 & 3 \\
\hline TOPLAM & $\mathbf{1 2 6}$ & $\mathbf{1 6}$ \\
\hline
\end{tabular}

Samakov şehrinde Müslüman sayısı gayrimüslim sayısına göre oldukça azdır. Şehirde Hacı Sinan Mahallesi olarak kaydedilen bir Müslüman mahalle tespit edilmiştir. Hac1 Sinan Mahallesinde 34 hane ve 3 mücerred Müslüman nüfus tespit edilmiştir (T.T.d, 370, s.115). Bun karş1lık, Samakov şehrinde 4 gayrimüslim mahallede 111 hane ve 25 mücerred mevcuttur (T.T.d, 370, s.115). Ayrica gayrimüslimlerin ikamet ettiği Bob Mahallesinde 1 Müslüman nüfus bulunmaktadır.

Tablo 9. Samakov Şebrinde Nüfusun Maballelere Göre Dă̆glımı

\begin{tabular}{lcclccc}
\hline & MÜSLÜMAN & \multicolumn{3}{c}{ GAYRIMÜSLİM } \\
\hline Mahalle & Hane & Mücerred & Mahalle & Hane & Mücerred & Müslüman \\
\hline Hac1 Sinan & 34 & 3 & Yovan & 57 & 10 & \\
\hline & & Nikisev-Radoslav & 22 & 7 & \\
\hline & Bob & 14 & 3 & 1 \\
\hline & Brankofça & 18 & 5 & \\
\hline
\end{tabular}

Osmanlı uç beylerinden Paşa Yiğit Bey tarafından Saruhan bölgesinden getirilen Türkmenler Üsküb’e yerleştirilmiştir ve Türk iskânı bu bölgenin demografik yapısını etkilemiştir (İnbaşı, 2012, s. 378). İskânın Üsküb’de 1530 yılında Müslüman nüfusun artışına da sebep olduğu söylenebilir. Edirne ve Filibe şehirlerinden sonra Müslüman nüfus sayısı bakımından en gelişmiş şehrin Üsküb olması bunun bir sonucudur.

Müslümanların yaşadığ1 51 mahalle bulunan Üsküb'de bu mahallelerde 530 hane ve 112 mücerred tespit edilmiştir (TT.d, 370, s.121-122). Üsküb'de 13 gayrimüslim mahallesi bulunmakta ve bu mahallelerde 200 hane ve 2 mücerred barınmaktadır (T’T.d, 370, s. 122-123). Ayrıca Üsküb şehrinde Yahudiyan Cemaati bulunmaktadır. Bu cemaatte 16 hane ve 5 mücerred tespit edilmiştir (TT'd, 370, s. 123).

Tablo 10. Üsküb Şehrinde Nüfusun Mahallelere Göre Dağılımı

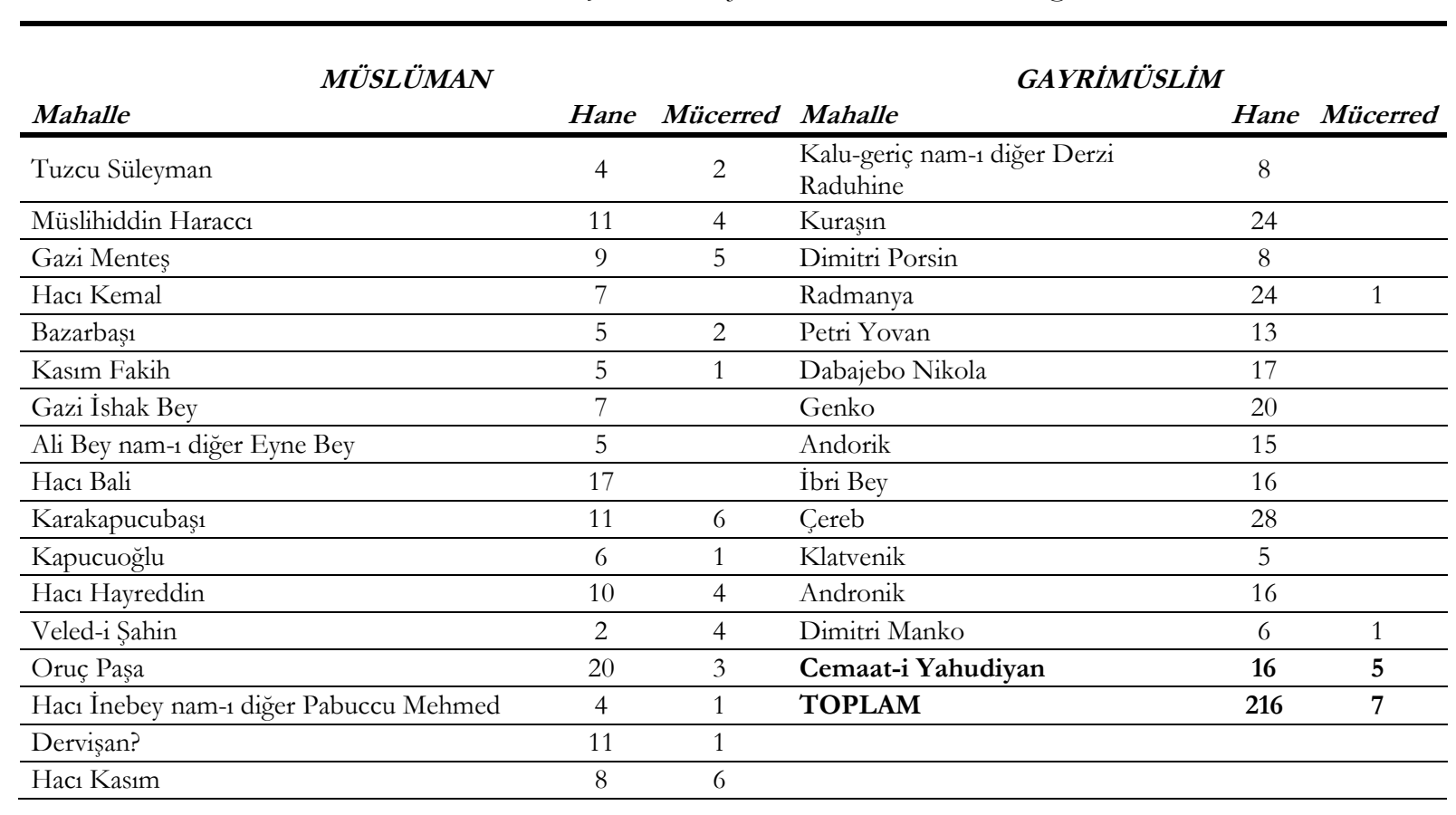




\begin{tabular}{|c|c|c|}
\hline Haraccı Şüca & 17 & \\
\hline Hac1 Kad1 & 13 & 3 \\
\hline Veled-i Kocacık & 15 & 1 \\
\hline Hac1 ... & 9 & 4 \\
\hline Derzi Baş1 & 3 & \\
\hline Debbağ Şahin & 23 & 8 \\
\hline Hamza Bey ser bevvabin-i İsa Bey & 8 & 2 \\
\hline Cami-i Kebir & 35 & 8 \\
\hline Hacı Muhyiddin & 5 & 3 \\
\hline İsa Bey-i Cedid & 5 & 4 \\
\hline Mehmed Çelebi veled-i İsa Bey & 17 & 4 \\
\hline Hoca Şems & 4 & 1 \\
\hline Tophane nam-1 diğer Ali Menteş & 39 & 9 \\
\hline Veled-i Bahri & 14 & 1 \\
\hline Hamza Kadı & 23 & 2 \\
\hline Yazıcı Şahin & 10 & \\
\hline Kuyumcuoğlu & 7 & 1 \\
\hline Derviş Ramazan & 9 & \\
\hline Hacı Hasan nam-1 diğer Ahiryanoğlu & 14 & 2 \\
\hline Yahya Paşa & 9 & 1 \\
\hline Taşhisar & 11 & \\
\hline İsa Bey nam-1 diğer Hatuncuk & 7 & 4 \\
\hline İshak Bey & 6 & 5 \\
\hline İsmail Voyvoda & 13 & \\
\hline Mehmed Çeleb-i Cedid & 6 & 1 \\
\hline Paşa Bey & 7 & 2 \\
\hline Katırlı & 19 & 3 \\
\hline Hacı Ömer & 16 & \\
\hline Hacı Şemseddin & 6 & \\
\hline Ahi İsa & 4 & 2 \\
\hline $\begin{array}{l}\text { Hacı Mehmed el-müteveffi onaltı Hacı } \\
\text { Mehmed }\end{array}$ & 6 & \\
\hline Dervişan & 5 & 1 \\
\hline Hizır Kazanc1 & 3 & \\
\hline TOPLAM & 530 & 112 \\
\hline
\end{tabular}

Kalkandelen şehri Rumeli sağkol kazaları içerisinde Müslüman nüfusun gayrimüslim nüfusa göre fazla olduğu şehirler arasındadır. Şehirde 5 gayrimüslim ve 6 Müslüman mahalle mevcuttur. Müslüman mahallelerde 62 hane ve 34 mücerred bulunurken, gayrimüslim mahallelerde 81 hane ve 7 mücerred yaşamaktadır (TT.d, 370, s. 137).

Tablo 11. Kalkandelen Şehrinde Nüfusun Mahallelere Göre Dağglımı

\begin{tabular}{|c|c|c|c|c|c|}
\hline \multicolumn{3}{|c|}{$M \ddot{U S L} \ddot{U} M A N$} & \multicolumn{3}{|l|}{ GAYRIMÜUSLIM } \\
\hline Mahalle & Hane & Mücerred & Mahalle & Hane & Mücerred \\
\hline Cami & 12 & 7 & ... nam-1 diğer Nikola & 19 & 1 \\
\hline Şeyh Ahmed & 9 & 4 & İstepan Lazari nam-1 diğer Niko Nikola & 13 & 2 \\
\hline Yeni & 10 & 5 & Rale Piçon? nam-1 diğer Dimitri Petkov & 24 & 2 \\
\hline İshak Bey & 11 & 3 & ... İvan nam-1 diğer ... Boğdan & 18 & 2 \\
\hline Hoca Müslihiddin & 13 & 12 & Pojdan Petkov & 7 & \\
\hline Ahmed Bey & 7 & 3 & & & \\
\hline TOPLAM & 62 & 34 & & 81 & 7 \\
\hline
\end{tabular}

Kırçova şehri gayrimüslim nüfusunun Müslüman nüfusa göre fazla olduğu Balkan sağkol şehirlerinden biridir. 4 Müslüman mahallesi bulunan Kırçova'da 63 hane ve 8 mücerred yaşamaktadır (TT.d, 370, s. 146). Gayrimüslimler 2 mahallede bulunmakta ve bu mahallelerde 83 hane ile 9 mücerred barınmaktadır (T'T.d, 370, s. 146). 
ALACA

XVI. Yüzyıl Başlarında Balkan Şehirlerinde Nüfus: Sağkol Kazaları Örneğinde Bir Tarihsel Demografi Denemesi

Tablo 12. Kurçova Şehrinde Nüfusun Maballelere Göre Dă̆zlımı

\begin{tabular}{lcclcc}
\hline & MÜSL ̈̈MAN & \multicolumn{3}{c}{ GAYRIMÜSLİM } \\
\hline Mahalle & Hane & Mücerred & Mahalle & Hane & Mücerred \\
\hline Cami & 31 & 5 & Şark & 44 & 6 \\
\hline Şeyh Sinan Halife & 4 & 2 & Arnako? & 39 & 3 \\
\hline Becice nam-1 diğer Sinan Bey & 13 & & & & \\
\hline İshak & 15 & 1 & & $\mathbf{8 3}$ & $\mathbf{9}$ \\
\hline TOPLAM & $\mathbf{6 3}$ & $\mathbf{8}$ & & & \\
\hline
\end{tabular}

Manastır, fethedilmesinden hemen sonra iskân politikası uygulanan Balkan şehirlerinden biridir. Manastır'a Ankara ve Karaman çevresinden Türkmen aşiretler getirilerek yerleştirilmiştir (Karta, 2015 , s. 460). Uygulanan bu iskân politikaları neticesinde 1530 yıllarında da Müslüman nüfusun gayrimüslim nüfustan fazla olduğu görülmektedir.

Rumeli'de sağkol kazalarından biri olan Manastır, nüfusu bakımdan Edirne, Üsküb, Filipe ve Kalkandelen'den sonra beşinci sırada yer almaktadır. Ayrıca Müslüman, gayrimüslim ve cemaatleri barındıran çok yönlü bir nüfus yapısına sahip olduğu görülmektedir. Manastır’da 21 Müslüman mahallesi, 10 gayrimüslim mahallesi ve 2 cemaat mevcuttur. Müslüman mahallelerde 432 hane ve 181 mücerred bulunurken (T'T.d, 370, s. 155), gayrimüslim mahallelerde 171 hane ve 8 mücerred bulunmaktadır (TT.d, 370, s. 156). Ayrıca cemaatlerde 72 hane ve 11 mücerred yaşamaktadırlar (TT.d, 370, s. 156).

Tablo 13. Manastr Şebrinde Nüfusun Maballelere Göre Dağ̀llmı

\begin{tabular}{|c|c|c|c|c|c|}
\hline \multicolumn{3}{|l|}{ MÜSLÜMAN } & \multicolumn{3}{|c|}{ GAYRIMUÜSLIM } \\
\hline Mahalle & Hane & Mücerred & Mahalle & Hane & Mücerred \\
\hline Mirali? & 42 & 30 & Todor Dimo & 29 & 1 \\
\hline İshak Çelebi nam-1 diğer İne Bey & 39 & 16 & Todor Miho nam-1 diğer Lukaç & 16 & \\
\hline Karaoğlan & 34 & 20 & Ral Nikola & 25 & \\
\hline Haydar Bey & 5 & 1 & Piyo Nikola nam-1 diğer Piyo Kob & 11 & \\
\hline Kara Debbağ nam-1 diğer ... & 21 & 11 & Piyo veled-i Habkov & 16 & \\
\hline Ŏgul Paşa & 31 & 21 & ... veled-i Pano ... & 22 & 2 \\
\hline Mehmed-i Siyah maa Mahalle-i İsmail & 24 & 7 & Türbe nam-1 diğer Kaliç & 17 & 3 \\
\hline Çavuş Ali & 21 & 7 & Kaliçe ... & 23 & 1 \\
\hline Firuz Subaş1 & 9 & 9 & Cedid-i Çömlekciyan & 10 & \\
\hline Yusuf Debbağ nam-1 diğer Suhte Hoca & 26 & 18 & Dımışk-1 Bey & 2 & 1 \\
\hline İlaldı Bey nam-1 diğer Dımışı Bey & 18 & 3 & Cemaat-i Zımmiyan & 19 & 5 \\
\hline Diğer Karaca Bey & 7 & 5 & Cemaat-i Yahudiyan & 43 & 6 \\
\hline Ryne & 17 & 6 & & & \\
\hline Kasım Çelebi & 11 & 4 & & & \\
\hline Hasan Bey & 1 & & & & \\
\hline Karacabey & 34 & & & & \\
\hline Bostancıŏ̆lu nam-1 diğer Hayyat Hızır & 11 & 8 & & & \\
\hline Hasan Subaşı & 12 & 6 & & & \\
\hline Kemal Bey nam-1 diğer Bet Mahalle & 17 & 4 & & & \\
\hline Yakub Bey & 9 & 5 & & & \\
\hline Hac1 Bey & 43 & & & & \\
\hline TOPLAM & 432 & 181 & TOPLAM & 233 & 19 \\
\hline
\end{tabular}

Pirlepe şehri, Rumeli sağkol kazaları içerisinde gayrimüslim nüfusun yoğun olarak barındığı şehirler arasında Edirne'den sonra ikinci sırada yer almaktadır. 1530 yılında Pirlepe, gayrimüslim mahalle sayıs1 bakımindan ilk sırada yer alır. 36 gayrimüslim mahallesi bulunan şehirde 471 hane ve 53 mücerred mevcuttur (T.T.d, 370, s. 167-168). Buna karşıllk 8 Müslüman mahalle bulunmakta ve bu mahallelerde 181 hane, 39 mücerred barınmaktadır (T.T.d, 370, s. 167). 
Tablo 14. Pirlepe Şebrinde Nüfusun Mahallelere Göre Dă̆zlımı

\begin{tabular}{|c|c|c|c|c|c|}
\hline \multicolumn{3}{|c|}{$M \ddot{U S L} \ddot{M} M A N$} & \multicolumn{3}{|c|}{ GAYRIMÜ̈SLİM } \\
\hline Mahalle & Hane & Mücerred & Mahalle & Hane & Mücerred \\
\hline Cami & 39 & 4 & Yani Kalko & 32 & 2 \\
\hline Tulaki Bey & 13 & 5 & Faliçar & 11 & 1 \\
\hline Tokatlu Hoca & 13 & 5 & Nikola Yano & 12 & 1 \\
\hline Hatib & 19 & 5 & Mirova & 13 & 1 \\
\hline Bayramlu Bey & 24 & 5 & Cüllehan & 10 & 1 \\
\hline Bali Bey & 45 & 10 & Kara-su & 7 & 1 \\
\hline Hacı Bey nam-1 diğer Kaba Sakal & 27 & 5 & Nikola Bogdan & 14 & \\
\hline \multirow[t]{29}{*}{ Hac1 İsa } & 1 & & İrinka & 10 & 1 \\
\hline & & & Cehre & 17 & \\
\hline & & & Timur Yano & 9 & 2 \\
\hline & & & Soğla nam-1 diğer Görgo Dimitri & 10 & 2 \\
\hline & & & $\ldots$ & 19 & 5 \\
\hline & & & Dorupar & 16 & 2 \\
\hline & & & Duşkov & 13 & 2 \\
\hline & & & Ternogoviliste & 11 & 1 \\
\hline & & & Rados ve Filibe & 18 & 1 \\
\hline & & & Kojoçar & 14 & 1 \\
\hline & & & Dorupar & 25 & 5 \\
\hline & & & Kale Bale & 8 & 2 \\
\hline & & & İştar & 23 & 3 \\
\hline & & & İsveti Todor & 12 & 3 \\
\hline & & & Franko-Pol & 14 & 4 \\
\hline & & & Carovik & 6 & \\
\hline & & & İstanşe & 15 & \\
\hline & & & Çigar & 16 & 2 \\
\hline & & & Berderun & 21 & \\
\hline & & & Yoyko Todor & 8 & 2 \\
\hline & & & Dabjenov? & 10 & \\
\hline & & & Nikola Vanko & 10 & 1 \\
\hline & & & $\ldots$ & 10 & \\
\hline & & & Radol & 11 & 3 \\
\hline & & & Pop-Melamiye & 6 & \\
\hline & & & $\ldots$ & 7 & \\
\hline & & & Nikifor & 6 & \\
\hline & & & Domkov & 16 & 4 \\
\hline & & & Dinçar & 11 & \\
\hline TOPLAM & 181 & 39 & TOPLAM & 471 & 53 \\
\hline
\end{tabular}

Gayrimüslim nüfusun yoğun olduğu şehirlerden biri de Köprülü'dür. 9 gayrimüslim mahallede 215 hane ve 13 mücerred kayıtlıdır (T.T.d, 370, s.178). Buna karşı 3 Müslüman mahalle mevcuttur ve bu mahallelerde 32 hane ve 10 mücerred tespit edilmiştir (T.T.d, 370, s.178). 
Tablo 15. Köprülü Şebrinde Nüfusun Maballelere Göre Dağgllmı

\begin{tabular}{|c|c|c|c|c|c|}
\hline \multirow[t]{2}{*}{ MÜSL ÜMAN } & & & \multicolumn{3}{|c|}{ GAYRIMÜ̈SLIM } \\
\hline & Hane & Mücerred & Mahalle & Hane & Mücererd \\
\hline Cami & 16 & 8 & Dobkov & 11 & 1 \\
\hline Yeni Köprü & 8 & 2 & Piyo Dobroslav & 36 & \\
\hline \multirow[t]{7}{*}{ Çevliler } & 8 & & Rale Kokor & 18 & 1 \\
\hline & & & Stale-Dovice & 19 & \\
\hline & & & Yanko-Bobo & 14 & \\
\hline & & & Bobo-Petri & 36 & \\
\hline & & & Hidmetkaran-1 köprü & 30 & \\
\hline & & & Kosdin & 24 & 3 \\
\hline & & & Büyük Köprü & 27 & 8 \\
\hline TOPLAM & 32 & 10 & TOPLAM & 215 & 13 \\
\hline
\end{tabular}

\section{Şehirlerde Toplam Nüfus}

Osmanlı şehirlerinde nüfus yerleşimi mahalleler şeklinde olmaktadır. Mahalle, birbirini tanıyan ve insanlar arasında sosyal dayanışmanın bulunduğu toplulukların yaşadığı mekânlardır (Ergenç, 1999, s.33). 1530 yılında mahalle yerleşiminin en dikkat çekici özelliği cemaatlerin bir arada yaşamasıdır. Din mahalle yerleşiminde en önemli etkendir. Müslüman ve gayrimüslimlerin yaşadığı mahallelerin farklı olması kendi dininden olanların birlikte yaşamak istediklerini göstermektedir.

Tablo 16. Balkanlar Sağkol Şebirlerinde Nüfus Dă̆gllmı

\begin{tabular}{|c|c|c|c|c|}
\hline Şehir & Müslüman (Hane) & Gayrimüslim (Hane) & Cemaat (Hane) & Toplam (Hane) \\
\hline Edirne & 2880 & 472 & 204 & 3556 \\
\hline Dimetoka & 166 & 145 & & 311 \\
\hline Ferecik & 113 & 37 & & 150 \\
\hline Keşan & 37 & & & 37 \\
\hline Kızılağaç & 47 & & & 47 \\
\hline Zağra-i Eskihisar & 513 & & & 513 \\
\hline Ípsala & 403 & 1 & & 404 \\
\hline Filibe & 609 & 81 & 66 & 756 \\
\hline Tatarpazar1 & 126 & & & 126 \\
\hline Samakov & 34 & 111 & & 145 \\
\hline Üsküb & 530 & 200 & 16 & 746 \\
\hline Kalkandelen & 62 & 81 & & 143 \\
\hline Kırçova & 63 & 83 & & 146 \\
\hline Manastır & 432 & 171 & 72 & 675 \\
\hline Pirlepe & 181 & 471 & & 652 \\
\hline Köprülü & 32 & 215 & & 247 \\
\hline TOPLAM & 6228 & 2068 & 358 & 8654 \\
\hline
\end{tabular}

Osmanlı Devleti'nin Balkanlar'da uyguladığı iskân politikası sonucunda şehirlerin büyük oranda Müslümanlaştığı görülmektedir. 370 Numaralı Tapu Tahrir Defteri'ne göre Balkanlar'da uygulanan iskân siyaseti genel olarak sürgün yöntemidir. 1530 yllında Balkanlara sürgün olarak gönderilen Müslüman haneler bulunmaktadır. Mesela, Kara İbrahim köyüne 14 hane Müslümanın, sürgün olarak gönderildiği tespit edilmiştir (T.T.d, 370, s.438). Yine "Cemaat-i Sürgünan” olarak kaydedilen Küçük Pınar köyünde 5, Divane köyünde 5, Delivük köyünde 70 hane olmak üzere birçok köyün sürgün olarak kaydedildiği tespit edilmiştir (T.T.d, 370, s.438).

\section{Sonuç}

Bu çalışmada, nesnel verilerinden hareketle Rumeli Eyaleti'nde Müslüman ve gayrimüslim nüfusun eyalette bağlı sancak merkezlerindeki dağılımı tespit edilmiştir. Balkanlar'da fetihlere başlamasıyla birlikte, Osmanlılar bu bölgede düzenli bir iskân politikası takip etmişlerdir. Bölgenin başlıca iskân unsuru Anadolu'dan gelen nüfustur. Bu nüfus Balkanların Türkleşmesi ve İslamlaşmasında büyük rol oynamıştır.

Osmanlıların Balkanlar'daki fetih istikameti bu bölgede sağkol, solkol ve ortakolun teşekkül etmesine neden olmuştur. Üzerinde durduğumuz sağkol, stratejik açıdan önemli bir yere sahiptir. Genişleyen fetihleri Osmanlı'nın Balkanlar'da Rumeli Eyaletini oluşturmasına neden olmuştur. Bu eyalet idarî, askerî 
ve ekonomik yönden Osmanlı'nın en önemli eyaletidir. Bu nedenle burada görevlendirilen beylerbeyi güvenilir ve devletin önde gelen devlet adamları arasından seçilmiştir.

1530 y1lına ait 370 Numaralı Tapu Tahrir Defteri’ne göre sağkolda 16 kaza mevcuttur. Bu kazaların nefsi yani şehrinde 333 Müslüman mahalle ve 106 gayrimüslim mahalle bulunmaktadır. Bu mahallelerde yaşayan Müslüman hane sayıs1 6228'dir. Gayrimüslim hane sayıs1 ise 2426 (bu toplam sayıya cemaat hane sayısı da eklenmiştir) olarak tespit edilmiştir. Bunların yanında Edirne, Filibe, Üsküb ve Manastır'da bunların dışında ayrı olarak kaydedilmiş cemaatler mevcuttur. Müslüman mahallelerinde gayrimüslim nüfus, gayrimüslim mahallerinde de Müslüman nüfus bulunmaktadır. $\mathrm{Bu}$ durum, Müslüman ve gayrimüslimlerin bir arada yaşama kültürünün mevcut olduğunun bir göstergesidir. 1530 yllında sadece Müslüman nüfusu barındıran şehirler Keşan, Kızılağaç, Zağra-i Eskihisar ve Tatarpazarı olmuştur. Diğer şehirler Müslüman ve gayrimüslim nüfusu barındırmaktadır.

Balkanlarda Müslüman ve gayrimüslim nüfusun şehirlerdeki yerleşimleri ve şehre dağglımları da ortaya konulmuştur. Her iki dini zümrenin de istediği mahallede ikamet ettiği görülmektedir. Sadece kendi dinine mensup insanların yaşadığı mahallelerin yanı sıra Müslüman ve gayrimüslim nüfusun bir arada barındığ1 mahallelerde mevcuttur. Osmanlı’nın her iki durumu da onayladığı görülmektedir.

\section{Etik Beyan}

"XVI. Yüsynl Başlarnda Balkan Şebirlerinde Nüfus: Sağkeol Kazalar Örneğinde Bir Taribsel Demografi Denemesi" başlıklı çalışmanın yazım sürecinde bilimsel kurallara, etik ve alıntı kurallarına uyulmuş; toplanan veriler üzerinde herhangi bir tahrifat yapılmamış ve bu çalışma herhangi başka bir akademik yayın ortamına değerlendirme için gönderilmemiştir. Bu araştırma doküman incelemesine dayalı olarak yapıldığından etik kurul kararı zorunluluğu bulunmamaktadır.

\section{Kaynakça}

\section{Arşiv Kaynakları}

BOA, TT.d 370 .

BOA, TT.d 167.

BOA, TT.d 20.

\section{Araştırma Eserler}

Acehan, A. (2008). Osmanlı Devleti’nin sürgün politikası ve sürgün yerleri. Uluslararası Sosyal Araşstrmalar Dergisi, 1 (5), 12-29.

Aktepe, M. (1951-53). XIV-XV. asırlarda Rumeli'nin Türkler tarafindan iskânına dair”, Türkiyat Mecmuası, X, 299-312.

Barkan, Ö. L. (1942). Osmanlı İmparatorluğunda bir iskân ve kolanizasyon metodu olarak vakıf ve temlikler I: İstila devirlerinin Türk dervişleri ve zâviyeler. VD, II, 279-386.

Barkan, Ö.L. (1952). Osmanlı İmparatorluğunda bir iskân ve kolanizasyon metodu olarak sürgünler. İstanbul Üniversitesi İktisat Fakültesi Mecmuasi, XI (1949-50), 524-569.

Baykara, T. (2002). Kaza. Diyanet İslam Ansiklopedisi, Ankara: TDV Yayınları, 25, 119-120.

Çalık, S. (2005). Cirmen sancağı örneğinde Balkanlar'da Osmanl düzeni (15.-16. Yü̈zyllar). Anlara: Bosna-Hersek Dostlar1 Vakfi Yayınları.

Doğru, H. (2000). XIII.-XIX yǚsyllar arasinda Rumeli'de sağ kolun siyasi, sosyal, ekonomik görüntüsü ve Kozluca kaz̧asi. Eskişehir: Anadolu Üniversitesi Edebiyat Fakültesi Yayınları.

Emecen, F. (1996). Gelibolu. Diyanet İslam Ansiklopedisi, İstanbul: TDV Yayınları, 14, 1-6.

Ergenç, Ö. (1999). Osmanlı klâsik düzeni ve özellikleri üzerine bazı açıllamalar. Osmanh Ansiklopedisi, Ankara: Yeni Türkiye Yayınları, 4, 32-39.

Faroqhi, S. (1984). Town and townsmen of Ottoman anatolia- trade, crafts and foods production in an urban setting, 1520-1560. Cambridge: Cambridge University Press.

Gökbilgin, M.G. (1964). Nahiye. Milli Eğitim Bakanhğg, İstanbul: MEB, IX, 37-39.

Gökbilgin, T. ( 1995). Kanunî Sultan Süleyman devri başlarında Rumeli Eyaleti, livaları, şehir ve kasabaları. Belleten, XX (78), Nisan 1956, Ankara: TTK, 247-295.

İnalcık, H. (1987). Hicrî 835 taribli sûret-i defter-i sancak-i Arvanid. Ankara: TTK.

İnalc1k, H. (1995). Eyalet. Diyanet İslam Ansiklopedisi, İstanbul: TDV Yayınlar1, 11, 548-550.

İnalc1k, H. (2008). Rumeli. Diyanet İslam Ansiklopedisi, İstanbul: TDV Yayınlar1, 35, 232-235.

İnalcık, H. (2011). Balkanlar'da Osmanlı fetihleri'nin sosyal koşulları. Adam Akademi, 2011 (1), 1-10. 
İnbaş1, M. (2012). Üsküb. Diyanet İslam Ansiklopedisi, İstanbul: TDV Yayınları, 42, 377-381.

Kaleshi, H. (1981). Türkler'in Balkanlar’a girişi ve islâmlaştırılma”. İstanbul Üniversitesi Edebiyat Fakültesi Tarih Enstitüsü Dergisi, 10-11 (1970-80),177-194.

Karta, N. (2015). Manastır şehrinin sosyal ve ekonomik durumu (1482-1615). Uluslararası Sosyal Araştırmalar Dergisi, 8 (41), 458-469.

Kıel, M. (1996). Filibe. Diyanet İslam Ansiklopedisi, İstanbul: TDV Yayınlar1, 13, 79-82.

Kiel, M. (1994). Dimetoka. Diyanet İslam Ansiklopedisi, İstanbul: TDV Yayınlar1, 9, 305-308.

Nejat, G. (1997). Hane. Diyanet İslam Ansiklopedisi, İstanbul: TDV Yayınlar1, 15, 552-553

Orhonlu, C. (1963). Osmanlı İmparatorluğunda aşiretleri iskân teşebbüsü (1691-1696). İstanbul: İstanbul Üniversitesi Edebiyat Fakültesi Yayınları.

Sami, Ş. (2001). Kâmûs-1 Türkî, İstanbul: Çağr1 Yay.

Şahin,I. (2009). Sancak. Diyanet İslam Ansiklopedisi, İstanbul: TDV Yayınları, 36, 97-99.

Turan, Ş. (1992). Bayezid II, Diyanet İslam Ansiklopedisi, İstanbul: TDV Yayınlar1, 5, 234-238.

\section{EXTENDED ABSTRACT}

In the Ottoman Empire, the most comprehensive population-based censuses were conducted in the 16th century. These censuses were conducted to determine the tax potential across the state in relation to the manorial system ("tımar" system) and, as a result, the cadastral record books were edited ("tahrir" books). Thanks to these books, called the cadastral record books, I was able to obtain information on the population structure of the region.

The Rumeli Administrative Organization is divided into sağkol, solkol and ortakol. The aim of this study is to determine the demographic structures of the Muslim and non-Muslim population in the settlements that are involved in the districts of "Edirne, Dimetoka, Ferecik, Keşan, Kızılağaç, Zağra-i Eskihisar, İpsala, Filibe, Tatarbazarı, Samakov, Üsküb, Kalkandelen, Kırçova, Manastır, Pirlepe ve Köprülü" named as Rumeli Sağkol in the light of the data presented by the cadastral record books No. 370. In this way, the characteristics and social relations of Muslim and non-Muslim neighborhoods will be tried to be revealed in the Balkan geography under the rule of the Ottoman Empire.

The Balkan was nominated by the Ottoman Empire as Rumeli. After conquering the Balkan lands, which were inspired by Romania and dominated by Byzantine, the Ottomans began to use the name of Rumeli. As a result of the marriage of Orhan Bey to the daughter of the Byzantine emperor, political and military alliances took place between the two states and, as a result of these alliances, the Ottomans set foot on Rumeli for the first time. During this period, the weakening of the central authority in Byzantium and its division into many states and feudal seniority facilitated the transition of the Ottoman state to Rumeli and its spread throughout the region.

As a result of the Ottoman settlement in Gallipoli, they continued their conquest along the roads built by the Romans and used by the Byzantines. As progress continued on these roads, the frontier regions were determined by the Ottomans. The first frontier region was in the direction of Tekfurdağ1, Çorlu and Istanbul from the coast; the second frontier region was in the middle on Konru Mount, in the direction of Malkara, Hayrabolu and Vize; and the third frontier regionwas the base for the conquests from the Meriç Valley to Ipsala, Dimetoka and Edirne. Later, in this order of frontier regions, Ipsala, Gümülcine, Serez, Kara Feriye and after they divided into two ramifications to Tirhala and Üsküb; the frontier region on the Sağkol (right-ramification) reached Yanbolu, Karin plain, Pravadi, and after it divided into two ramifications, one to Tirnova and Niğbolu and the other to Dobruca. The middleramification divided into Çirmen, Zagra, Filibe (Plovdiv), and from there it reached to Sofia and Niş, or Köstendil and Üsküb. The conquests in these three directions constituted the Sancaks (Sancak is the name given to military administration regions during the Ottoman period.) districts of sağkol (rightramification), solkol (left- ramification) and ortakol (middle- ramification) of Rumeli.

Population refers to the number of people living in settlements in a country, a region. Information about the population in the 15th and 16th centuries in the Ottoman Empire is obtained from land registry books/cadastral record books (Tapu-Tahrir books). These books such as to reveal the names of the settlement areas, the boundaries and the administrative characteristics of a region. In addition, these books contain statistical data that will reveal the number, structure and changes that have occurred over time and the reasons for these changes.

The population of the cities called "nefs" was evaluated in Rumeli Sağkol (Right- Ramification) District. In general, the word "nefs" found in thecadastral record books is defined as a city. However, the word nefs does not fully express the concept of the city. The Muslim population was recorded as 
households and unmarried people ("mücerred") in the Sağkol (Right- Ramification) District of Rumeli State.

The Muslim population was most present in Edirne in Rumeli, in the cities of Sağkol District. A total of 2880 Muslim households and 387 unmarried individuals were registered in the city of Edirne, in 144 neighborhoods. There were also a non-Muslim population in 47 households in these Muslim neighborhoods. This, in turn, indicates that there is a culture of coexistence between Muslim and nonMuslim elements. However, the city of Edirne was rank first in the districts of Sağkol (RightRamification) in terms of both the number of neighborhoods and the population.

In addition, there are eight Jewish communities in Edirne under the title "Cemaat-i Yahudiyan". A total of 204 households and 6 unmarried individuals were registered in these communities. It was observed that Jewish communities were recorded according to the names of the regions from which they were originated. It was expected that the Jews who lived here were Jews who had been forced to emigrate from many parts of Europe in the 15th century. It is known that some of the Jews were brought to Ottoman territory by ships sent by Bayezid II. The fact that the land registry book / cadastral record book (Tapu-Tahrir book) we are working on is part of the year 1530 is an important factor that reinforces this assumption.

There were 166 Muslim households and 44 unmarried individuals in 15 Muslim neighborhoods in the city of Dimetoka. In contrast, there were 145 households in 4 non-Muslim neighborhoods and 3 individuals registered as unmarried. "Dimitri aka Yahudiyan", where non-Muslims resided, was the neighborhood where Jews resided, as the name suggests.

Ferecik was the southernmost settlement on the coast of the Mediterranean Sea from the districts of Rumeli Sağkol (Right- Ramification). During the Kanuni period, 133 households and 61 unmarried Muslims resided in 7 neighborhoods in Ferecik city. Non-Muslims were presented in total under the title "mahalle-i gebran". Accordingly, 37 non-Muslim populations were identified in the city of Ferecik.

Keşan was rank the second after the city of Köprülü among the cities with a small number of population within Rumeli Sağkol District. While there was a Muslim population in the city of Keşan, there was no non-Muslim population. In Keşan, which had only the Mercan neighborhood, there were 37 households and 7 unmarried Muslim populations in this neighborhood.

In 1530, the city of Kızılağaç was also one of the cities with a small population. There are 47 households and 18 unmarried individuals registered in 4 Muslim neighborhoods. Again, as in the city of Keşan, there was only a Muslim population in the city of Kızılağaç. The city of Ipsala had 14 Muslim neighborhoods and 403 households and 142 families were residing in this neighborhood.

The city of Filibe (Plovdiv) had a total of 609 households and 127 Muslim households in 29 neighborhoods. In addition, the city of Filipe had 4 non-Muslim neighborhoods and 2 neighborhoods, and has 147 households and 16 non-Muslim unmarried population. Tatarpazar1 was one of the only cities in the Balkans in Sağkol District with a Muslim population. Tatarpazarı, which had 7 neighborhoods, had a total of 126 households and 16 unmarried individuals.

In Üsküb, which had 51 neighborhoods where Muslims resided, 530 households and 112 unmarried individuals resided in these neighborhoods. There were 13 neighborhoods where non-Muslims resided, and these neighborhoods contained 200 households and 2 unmarried individuals. There were also a Jewish community in the city of Üsküb. There were 16 households and 5 unmarried individuals determined in this neighborhood.

There are 5 non-Muslim and 6 Muslim neighborhoods in Kalkandelen. There are 62 households and 34 unmarried individuals residing in Muslim neighborhoods, while 81 households and 7 unmarried individuals residing in non-Muslim neighborhoods.

There were 63 households and 8 unmarried individuals residing in Kurçova, which had 4 Muslim neighborhoods. Non-Muslims were located in two neighborhoods and there were 83 households and 9 families residing in these neighborhoods. Manastır had 21 Muslim neigborhoods, 10 non-Muslim neighbourhoods and 2 communities. There were 432 households and 181 unmarried individuals in Muslim neighborhoods, while there were 171 households and 8 unmarried individuals in non-Muslim neighborhoods. There were also 72 households and 11 unmarried individuals residing in the communities. 
ALACA

XVI. Yüzyıl Başlarında Balkan Şehirlerinde Nüfus: Sağkol Kazaları Örneğinde Bir Tarihsel Demografi Denemesi

In 1530, Pirlepe ranks first in terms of the number of non-Muslim neighborhoods. There were 471 households and 53 unmarried individuals in the city, which had 36 non-Muslim neighborhoods (T.T.d, 370, p.167-168). In contrast, there were 8 Muslim neighborhoods, and there were 181 households and 39 unmarried individuals residing in these neighborhoods.

Köprülü is one of the cities with a non-Muslim population density. In 9 non-Muslim neighborhoods, there were 215 households and 13 unmarried individuals. There were three Muslim neighborhoods, and 32 households and 10 unmarried individuals were identified in these neighborhoods.

According to the cadastral record book No. 370 of 1530, there were 16 districts in the Sağkol (rightramification). There were 333 Muslim neighborhoods in the "neft" of these districts, i.e. the city, while there were 106 non-Muslim neighborhoods. The total number of Muslim households residing in these neighborhoods was 6228. The number of non-Muslim households was 2426 (the number of communal households was also added to this total number). Besides these, there were separately recorded communities in Edirne, Filibe (Plovdiv), Üsküb and Manastır. 